\title{
MEDIUM OPTIMIZATION FOR ANTIMICROBIAL PRODUCTION BY NEWLY SCREENED LACTIC ACID BACTERIA
}

\author{
Rohmatussolihat $^{1 *}$, Puspita Lisdiyanti ${ }^{1}$, Yopi $^{1}$, Yantyati Widyastuti ${ }^{1}$, and Endang Sukara ${ }^{1}$ \\ ${ }^{1}$ Research Center for Biotechnology, Indonesian Institute of Sciences (LIPI), Jalan Raya Bogor Km. \\ 46, Cibinong 16911, Indonesia
}

\begin{abstract}
Lactic acid bacteria (LAB) are important for prevention of spoilage and pathogenic bacterial growth in foods due to their ability to generate antimicrobial substances. The objectives of this study were to screen LAB for antimicrobial activity and to optimize culture medium for antimicrobial production using Response Surface Methodology (RSM) with Central Composite Design (CCD). Optimization of antimicrobial production of selected $\mathrm{LAB}$ was conducted with different combinations of glucose, $\mathrm{NaCl}$, inoculum, and temperature. Our experimental results show that from 129 LAB isolates, 55 show significant inhibition against Bacillus subtilis, Escherichia coli, Micrococcus luteus, Staphylococcus aureus, Aspergillus niger, and Candida albicans. No isolates inhibited the growth of Aspergillus flavus. Lactobacillus plantarum LIPI13-2-LAB011 was selected for further study on culture medium optimization to inhibit the growth of C. albicans. Statistical analysis reveals that the production of antimicrobial substances was significantly influenced by temperature, $\mathrm{NaCl}$, and concentration of glucose. Furthermore, the optimum concentrations of glucose, concentration of inoculum, temperature, and $\mathrm{NaCl}$ were $1.63 \%, 3.03 \%, 33.74^{\circ} \mathrm{C}$, and $3.4 \%$, respectively, with a maximum predicted inhibition index of 1.916, which increased 3.56-fold compared to that obtained in medium before optimization processes. The result was confirmed as when the optimum concentration of nutritions used, the inhibition index increased 3.12-fold.
\end{abstract}

Keywords: Antimicrobial, Lactobacillus plantarum, Response Surface Methodology

*Corresponding author: Rohmatussolihat

Cibinong Science Center, Jl. Raya Bogor Km. 46, Cibinong 16911, Indonesia

Tel. +62-21-8754587, Fax. +62-21-87754588

E-mail.rohmatussolihat@gmail.com

\section{Introduction}

Proliferation of spoilage and pathogenic microorganisms cause a problem in food industry. Food borne pathogens may cause human illness and death. Food-borne diseases are mainly caused by Bacillus subtilis, Escherichia coli, Staphylococcus aureus, Candida albicans, parasites, and viruses (Vincent et al., 2010; Kadariya et al., 2014; Martins et al., 2014). The application of antimicrobial compounds is a method commonly employed to eradicate food borne pathogens. $\mathrm{LAB}$ are extremely important for their capacity to produce antimicrobial and their ability to prevention of the growth of spoilage and pathogenic bacteria in foods (Galvez et al., 2008; Saranraj, 2012). LAB are a group of bacteria that generate most of the antimicrobial compounds, are recognized as non-toxic microorganisms, and exhibits various health properties to human (Wessels et al., 2004; Ghrairi et al., 2008; Yang et al., 2012).

The presence of LAB in food can extend the shelf life of foods through its ability to produce various substances with antimicrobial properties such as organic acids, short chain fatty acids, diacetyl, hydrogen peroxide, bacteriocin and bacteriocin-like compounds, enzymes and antimicrobial-bioactive peptides (Liong and Shah, 2005; Gálvez et al., 2007; Tan et al., 2014).

The production of antimicrobial compounds by $\mathrm{LAB}$ may be influenced by various factors e.g. nutrient and fermentation conditions. Those factors may be optimized by statisticalbased approaches. Response Surface Methodology (RSM) has been extensively used in fermentation media optimization 
(Khurana et al., 2007; Yu et al., 2008; Yuan et al., 2008; Mu et al., 2009). This important statistical technique was employed for multiple regression analysis by using quantitative experimental data obtained from properly designed experiments using Central Composite Design (CCD) (Bezerra et al., 2008). This method uses mathematical models to analyze the experimental data and to predict the relationship between the response and the variables (Bezerra et al., 2008; Rajendran \& Thangavelu, 2007). This method offers several advantages over conventional methods in being rapid and reliable and to easily shortlist significant nutrients, helping to understand the interactions among the nutrients at various concentrations and reduce the total number of experiments while improving product yield, reduce process variability, as well as reduce development time and overall costs (Chauhan et al., 2007; Rohmatussolihat, 2013; Yu et al., 2008).

The purpose of this study was to screen LAB for antimicrobial activity and to optimize culture medium for antimicrobial production using Response Surface Methodology (RSM) with Central Composite Design (CCD).

\section{Materials and Methods}

A total of $129 \mathrm{LAB}$ isolates were used for antimicrobial screening. Those isolates are obtained from the Indonesian Culture Collection (InaCC), Indonesian Institute of Sciences. Those isolates undergone a longterm storage in sterile glycerol $\left(150 \mathrm{~mL} . \mathrm{L}^{-1}\right)$ and stored at $-80^{\circ} \mathrm{C}$ (Badis et al., 2004). Those isolates are also stored in L-drying ampoules. The medium used in cultivating LAB and production of antimicrobial were (i) de Man Rogosa Sharpe (MRS) broth (Merck) at pH 10 with the addition of 100 g. $\mathrm{L}^{-1} \mathrm{NaCl}$ (Merck) and (ii) Trypticase Soy Yeast Extract (TSYE) broth at $\mathrm{pH} 6$ with or without the addition of 100 g. $\mathrm{L}^{-1} \mathrm{NaCl}$ (Merck) depending on the isolates used. The composition of TSYE broth was 33 g.L. - $^{-1}$ Trypticase Soy Broth (TSB) (Merck) and 3 g.L $\mathrm{L}^{-1}$ of yeast extract (Merck).

Two loops of LAB isolates taken from glycerol stock were inoculated into $10 \mathrm{~mL}$ of sterile MRS media and incubated at $30{ }^{\circ} \mathrm{C}$. After 48 hours, the cell culture was centrifuged at $3,220 \times \mathrm{g}$ at $4{ }^{\circ} \mathrm{C}$ for 10 minutes to obtain cell-free supernatant (CFS). The CFS was used for antimicrobial testing by using disc diffusion method (Balouiri et al., 2016).

\section{Test Organisms}

Bacillus subtilis BTCC B-612, Escherichia coli BTCC B-548, Micrococcus luteus BTCC B-552, Staphylococcus aureus BTCC B-611, Candida albicans BTCC Y-33, Aspergillus niger BTCC F-62, and Aspergillus flavus BTCC F-69 were chosen as test organisms for antimicrobial assays. Those testing microbes were obtained from Biotechnology Culture Collection (BTCC), Research Center for Biotechnology, Indonesian Institute of Sciences. The reference of the test bacteria is the basis of initial screening in antimicrobial testing. If one isolate has activity, then continued for further test.

One loop of testing bacteria were cultured in $5 \mathrm{~mL}$ Nutrient Broth (NB) (Merck) at $30^{\circ} \mathrm{C}$, while testing fungi were cultured in $5 \mathrm{~mL}$ Potato Dextrose Broth (PDB) (Merck) at $30{ }^{\circ} \mathrm{C}$ and incubated for $24 \mathrm{~h}$ in a shaker incubator.

\section{Disc Diffusion Assay for Antimicrobial Activity}

Petri dish containing $15 \mathrm{~mL}$ of solidified Muller Hinton Agar (Merck) for bacteria or Sabaraud Agar (Merck) for fungi overlaid with $5 \mathrm{~mL}$ of soft agar was inoculated with each of test organism. The concentration of testing microbes was $0.1 \%(\mathrm{v} / \mathrm{v})$ for $S$. aureus and $B$. subtilis, $0.2 \%(\mathrm{v} / \mathrm{v})$ for E. coli, and $0.5 \%(\mathrm{v} / \mathrm{v})$ for $M$. luteus, $C$. albicans, A. niger, and $A$. flavus (Miyadoh \& Otoguro, 2004). A total of $30 \mu \mathrm{L}$ of CFS was injected on a paper disc and left to dry. The disc was then placed on the agar containing test organisms, and were incubated at $30{ }^{\circ} \mathrm{C}$ for 24 hours (Bromberg et al., 2004; Saranya and Hemashenpagam, 2011).

Antimicrobial activity from CFS was evaluated by measuring the zone of inhibition/clearing zone against the test organisms. Microbial inhibition was visually appraised as the diameter of the inhibition zones surrounding the discs (disc diameter included) and recorded in millimeters. Inhibition zone formed around the paper disc was observed and measured using a caliper. The agar disc diffusion bioassay were performed in duplicates. The inhibition index was measured according to the following formulation: inhibition index $=$ (inhibition zone 
diameter $(\mathrm{mm})$ - discs diameter $(\mathrm{mm})) /($ discs diameter $(\mathrm{mm})$ ).

\section{Optimization for Antimicrobial Production}

Optimization of antimicrobial production was performed by using RSM with the CCD. The design and data analysis was carried out using Design-Expert Software Statistics 7. The used design is based upon Leal-Sánchez et al. (2002) that consists of four variables namely glucose $\left(\mathrm{X}_{1}\right)$, inoculum $\left(\mathrm{X}_{2}\right)$, temperature $\left(\mathrm{X}_{3}\right)$, and $\mathrm{NaCl}\left(\mathrm{X}_{4}\right)$ with 5 level combinations (Table 1). According to this design, 30 runs were conducted containing six replications at the central point for the estimating the purely experimental uncertainly variance ( $\mathrm{Mu}$ et al., 2009). The response surface analysis was based on the multiple linear regressions taking into account the main, quadratic and interaction effects, according to the following equation:

$Y=\beta_{0}+\sum_{i=1}^{k} \beta_{i} X_{i}+\sum_{i=1}^{k} \beta_{i i} X_{i}^{2}+\sum_{i=1}^{k-1} \sum_{j=2}^{k} \beta_{i j} X_{i} X_{j} \quad$ (Eq.1) $\beta_{0}$ : scaling constant (intersept), $\beta_{i}-\beta \mathrm{ij}$ : regression estimates

Table 1. Coded and uncoded values of the experimental variables

\begin{tabular}{lrrrrrr}
\hline Variables & & \multicolumn{5}{c}{ Code Values } \\
\cline { 3 - 7 } & & -2 & -1 & 0 & +1 & +2 \\
\hline Glucose (\%) & $\mathrm{X}_{1}$ & 0.5 & 1.0 & 1.5 & 2.0 & 2.5 \\
$\begin{array}{l}\text { Inoculum } \\
\text { (\%) }\end{array}$ & $\mathrm{X}_{2}$ & 1.0 & 2.0 & 3.0 & 4.0 & 5.0 \\
$\begin{array}{l}\text { Temperature } \\
\left({ }^{\circ} \mathrm{C}\right)\end{array}$ & $\mathrm{X}_{3}$ & 25.0 & 30.0 & 35.0 & 40.0 & 45.0 \\
$\mathrm{NaCl}(\%)$ & $\mathrm{X}_{4}$ & 2.0 & 3.0 & 4.0 & 5.0 & 6.0 \\
\hline
\end{tabular}

Optimization of antimicrobial production was conducted by inoculating the selected isolates into $25 \mathrm{~mL}$ of optimized MRS Broth medium and incubated at temperature that varies based on the design of experiments using RSM for 48 hours (Al-Allaf et al., 2009; Leal-Sánchez et al., 2002). The cultures were centrifuged at $3,220 \mathrm{~g}$ at $4{ }^{\circ} \mathrm{C}$ for 10 minutes. The CFS was then analyzed for its antimicrobial.

\section{Results}

\section{Screening for Antimicrobial Production}

The CFS from 129 LAB isolates were screened for its antimicrobial properties against test organisms. The results are depicted in Table 2. Out of 129 LAB isolates, 55 isolates $(42.6 \%)$ show significant inhibition against test organisms with varying degrees and 74 isolates $(57.4 \%)$ did not show inhibition. Upon further screening, from 55 isolates, significant inhibition was observed against B. subtilis, E. coli (8), M. luteus (2), S. aureus (1), C. albicans (36), A. niger (32). None of the 129 isolates could inhibit $A$. flavus. The number of LAB that can inhibit $C$. albicans was the highest among all test organisms. The inhibition index of antimicrobial activity of LAB isolates ranged between 0.21-0.31, 0.46-0.54, 0.28, 0.65, 0.170.82, and 0.06-0.28 for B. subtilis, E. coli, M. luteus, S. aureus, C. albicans, A. niger, respectively. Inhibition index of $L$. plantarum LIPI13-2-LAB060 and L. plantarum LIPI13-2LAB061 showed the highest value of 0.82 for C.albicans. Only one isolate (L. plantarum LIPI13-2-LAB011) showed wide spectrum activity against four test organisms. Therefore, L. plantarum LIPI13-2-LAB011 was selected for further evaluation. The inhibition index of antimicrobial activity of $L$. plantarum LIPI132-LAB011 was $0.23,0.65,0.42,0.12$ against B. subtilis, S. aureus, C. albicans, and A. niger, respectively. Inhibition index of $L$. plantarum LIPI13-2-LAB011 for S.aureus was the highest compared to other test microbes, but when analysed by RSM CCD showed the model was not significant (data not shown). $C$. albicans was chosen as a target for optimization.

\section{Optimization of medium for producing antimicrobial activity}

A total of 30 experiments with different combination of variables were performed to examine the combined effect of four independent variables on antimicrobial activity from L. plantarum LIPI13-2-LAB011 against C. albicans. The CCD and experimental yields are shown in Table 3. The highest output of inhibition index observed was 2.108 at run 27 (Table 3). In order to determine the maximum inhibition index corresponding to the optimum levels of glucose, inoculum, temperature and $\mathrm{NaCl}$, a quadratic model was proposed to calculate the optimum levels of these variables in producing antimicrobial activity. 
Table 2. Antimicrobial activity of LAB tested by disc diffusion assay

\begin{tabular}{|c|c|c|c|c|c|c|c|c|c|}
\hline \multirow[t]{2}{*}{ No. } & \multirow[t]{2}{*}{ Genus and Species Name } & \multirow[t]{2}{*}{ Code } & \multicolumn{7}{|c|}{ Inhibition index against ${ }^{\mathrm{b}}$ : } \\
\hline & & & $B s$ & $E c$ & $M l$ & $S a$ & $\mathrm{Ca}$ & $A n$ & $A f$ \\
\hline 1 & Bifidobacterium psychraerophilum & LIPI13-2-LAB041 & - & - & - & - & - & 0.21 & - \\
\hline 2 & Enterococcus faecalis & LIPI13-2-LAB078 & - & - & - & - & - & 0.14 & - \\
\hline 3 & Enterococcus faecium & LIPI13-2-LAB133 & - & 0.52 & - & - & - & - & - \\
\hline 4 & Lactobacillus casei & LIPI13-2-LAB128 & 0.31 & - & - & - & 0.29 & - & - \\
\hline 5 & Lactobacillus dextrinicus & LIPI13-2-LAB012 & - & - & - & - & 0.24 & 0.12 & - \\
\hline 6 & Lactobacillus farciminis & LIPI13-2-LAB129 & - & - & - & - & 0.19 & - & - \\
\hline 7 & Lactobacillus fermentum & LIPI13-2-LAB051 & - & - & - & - & 0.50 & 0.13 & - \\
\hline 8 & Lactobacillus fermentum & LIPI13-2-LAB168 & - & - & - & - & 0.17 & - & - \\
\hline 9 & Lactobacillus mali & LIPI13-2-LAB043 & - & - & - & - & - & 0.13 & - \\
\hline 10 & Lactobacillus nagelii & LIPI13-2-LAB199 & - & - & - & - & 0.43 & - & - \\
\hline 11 & Lactobacillus paracasei & LIPI13-2-LAB077B & - & 0.46 & - & - & 0.50 & 0.14 & - \\
\hline 12 & Lactobacillus paracasei & LIPI13-2-LAB136 & - & - & - & - & 0.50 & - & - \\
\hline 13 & Lactobacillus paracasei & LIPI13-2-LAB142 & - & - & - & - & 0.57 & - & - \\
\hline 14 & Lactobacillus paracasei & LIPI13-2-LAB149 & - & - & - & - & 0.50 & - & - \\
\hline 15 & Lactobacillus plantarum & LIPI13-2-LAB011 & 0.23 & - & - & 0.65 & 0.42 & 0.12 & - \\
\hline 16 & Lactobacillus plantarum & LIPI13-2-LAB044 & 0.27 & - & - & - & 0.80 & - & - \\
\hline 17 & Lactobacillus plantarum & LIPI13-2-LAB050 & - & - & - & - & 0.50 & 0.13 & - \\
\hline 18 & Lactobacillus plantarum & LIPI13-2-LAB060 & - & - & - & - & 0.82 & 0.10 & - \\
\hline 19 & Lactobacillus plantarum & LIPI13-2-LAB061 & - & - & - & - & 0.82 & 0.24 & - \\
\hline 20 & Lactobacillus plantarum & LIPI13-2-LAB076 & - & 0.46 & - & - & 0.79 & 0.17 & - \\
\hline 21 & Lactobacillus plantarum & LIPI13-2-LAB077A & - & 0.54 & - & - & 0.67 & 0.17 & - \\
\hline 22 & Lactobacillus plantarum & LIPI13-2-LAB087 & - & 0.52 & - & - & 0.72 & 0.14 & - \\
\hline 23 & Lactobacillus plantarum & LIPI13-2-LAB099 & - & - & - & - & 0.58 & 0.28 & - \\
\hline 24 & Lactobacillus plantarum & LIPI13-2-LAB130 & - & - & - & - & 0.19 & - & - \\
\hline 25 & Lactobacillus plantarum & LIPI13-2-LAB145 & 0.21 & - & - & - & - & - & - \\
\hline 26 & Lactobacillus plantarum & LIPI13-2-LAB147 & - & - & - & - & 0.50 & - & - \\
\hline 27 & Lactobacillus plantarum & LIPI13-2-LAB178 & 0.27 & - & 0.28 & - & 0.37 & - & - \\
\hline 28 & Lactobacillus plantarum & LIPI13-2-LAB184 & - & - & - & - & 0.62 & - & - \\
\hline 29 & Lactobacillus plantarum & LIPI13-2-LAB206 & - & - & - & - & 0.50 & - & - \\
\hline 30 & Lactobacillus plantarum & LIPI13-2-LAB210 & 0.23 & 0.52 & - & - & - & - & - \\
\hline 31 & Lactobacllus fermentum & LIPI13-2-LAB057 & - & - & - & - & 0.49 & 0.08 & - \\
\hline 32 & Lactobacllus fermentum & LIPI13-2-LAB073 & - & - & - & - & 0.36 & 0.14 & - \\
\hline 33 & Lactobacllus fermentum & LIPI13-2-LAB074 & - & - & - & - & 0.66 & - & - \\
\hline 34 & Lactobacllus fermentum & LIPI13-2-LAB084 & - & 0.47 & - & - & - & - & - \\
\hline 35 & Lactobacllus fermentum & LIPI13-2-LAB088 & - & - & - & - & 0.47 & 0.14 & - \\
\hline 36 & Lactobacllus fermentum & LIPI13-2-LAB100 & - & - & - & - & 0.33 & 0.28 & - \\
\hline 37 & Lactobacllus fermentum & LIPI13-2-LAB101 & - & - & - & - & 0.33 & 0.28 & - \\
\hline 38 & Leuconostoc mesenteroides & LIPI13-2-LAB049 & - & - & - & - & 0.28 & 0.13 & - \\
\hline 39 & Leuconostoc mesenteroides & LIPI13-2-LAB059 & - & - & - & - & 0.49 & 0.28 & - \\
\hline 40 & Leuconostoc mesenteroides & LIPI13-2-LAB067 & 0.26 & - & - & - & 0.42 & 0.14 & - \\
\hline 41 & Leuconostoc mesenteroides & LIPI13-2-LAB081 & - & - & - & - & - & 0.14 & - \\
\hline 42 & Leuconostoc mesenteroides & LIPI13-2-LAB221 & - & 0.54 & - & - & - & - & - \\
\hline 43 & Pediococcus pentosaceus & LIPI13-2-LAB122 & - & - & - & - & 0.29 & - & - \\
\hline 44 & Tetragenococcus halophilus & LIPI13-2-LAB019 & - & - & - & - & - & 0.12 & - \\
\hline 45 & Tetragenococcus halophilus & LIPI13-2-LAB024 & - & - & - & - & - & 0.14 & - \\
\hline 46 & Tetragenococcus halophilus & LIPI13-2-LAB027 & - & - & - & - & - & 0.14 & - \\
\hline 47 & Tetragenococcus halophilus & LIPI13-2-LAB033 & - & - & - & - & - & 0.14 & - \\
\hline 48 & Tetragenococcus halophilus & LIPI13-2-LAB038 & - & - & - & - & - & 0.06 & - \\
\hline 49 & Tetragenococcus halophilus & LIPI13-2-LAB042 & - & - & - & - & - & 0.21 & - \\
\hline 50 & Tetragenococcus halophilus & LIPI13-2-LAB102 & - & - & - & - & - & 0.28 & - \\
\hline 51 & Tetragenococcus muriaticus & LIPI13-2-LAB003 & - & - & - & - & - & 0.12 & - \\
\hline 52 & Tetragenococcus muriaticus & LIPI13-2-LAB006 & - & - & - & - & - & 0.06 & - \\
\hline 53 & Weissella confusa & LIPI13-2-LAB160 & - & - & - & - & 0.22 & - & - \\
\hline 54 & Weissella confusa & LIPI13-2-LAB170 & - & - & - & - & 0.20 & - & - \\
\hline 55 & Weissella confusa & LIPI13-2-LAB223 & - & - & 0.28 & - & - & - & - \\
\hline
\end{tabular}

${ }^{a}$ Antimicrobial activity detected as inhibition index

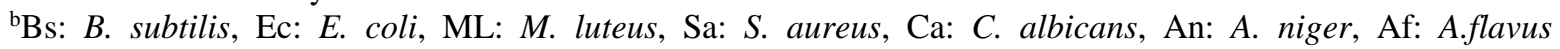


Table 3. Central Composite Design (CCD) and experimental antimicrobial activity yield of $L$. plantarum LIPI13-2-LAB011 against $C$. Albican.

\begin{tabular}{cccccc}
\hline \multirow{2}{*}{ No. } & \multicolumn{5}{c}{ Variables $^{*}$} \\
\cline { 2 - 6 } & $\mathrm{X}_{1}$ & $\mathrm{X}_{2}$ & $\mathrm{X}_{3}$ & $\mathrm{X}_{4}$ & Inhibition index \\
\hline 1 & 1 & 2 & 30 & 3 & 0.850 \\
2 & 2 & 2 & 30 & 3 & 1.075 \\
3 & 1 & 4 & 30 & 3 & 0.575 \\
4 & 2 & 4 & 30 & 3 & 1.408 \\
5 & 1 & 2 & 40 & 3 & 0.808 \\
6 & 2 & 2 & 40 & 3 & 0.892 \\
7 & 1 & 4 & 40 & 3 & 0.600 \\
8 & 2 & 4 & 40 & 3 & 0.358 \\
9 & 1 & 2 & 30 & 5 & 0.658 \\
10 & 2 & 2 & 30 & 5 & 0.908 \\
11 & 1 & 4 & 30 & 5 & 0.750 \\
12 & 2 & 4 & 30 & 5 & 0.883 \\
13 & 1 & 2 & 40 & 5 & 0 \\
14 & 2 & 2 & 40 & 5 & 0.167 \\
15 & 1 & 4 & 40 & 5 & 0.292 \\
16 & 2 & 4 & 40 & 5 & 0.217 \\
17 & 0.5 & 3 & 35 & 4 & 0.217 \\
18 & 2.5 & 3 & 35 & 4 & 1.200 \\
19 & 1.5 & 1 & 35 & 4 & 1.350 \\
20 & 1.5 & 5 & 35 & 4 & 1.975 \\
21 & 1.5 & 3 & 25 & 4 & 0.892 \\
22 & 1.5 & 3 & 45 & 4 & 0.167 \\
23 & 1.5 & 3 & 35 & 2 & 2.058 \\
24 & 1.5 & 3 & 35 & 6 & 0.725 \\
25 & 1.5 & 3 & 35 & 4 & 1.508 \\
26 & 1.5 & 3 & 35 & 4 & 1.925 \\
$\mathbf{2 7}$ & $\mathbf{1 . 5}$ & $\mathbf{3}$ & $\mathbf{3 5}$ & $\mathbf{4}$ & $\mathbf{2 . 1 0 8}$ \\
28 & 1.5 & 3 & 35 & 4 & 1.767 \\
29 & 1.5 & 3 & 35 & 4 & 1.608 \\
30 & 1.5 & 3 & 35 & 4 & 1.900 \\
\hline $\mathrm{X}_{1}: \mathrm{glucose}(\%), \mathrm{X}_{2}: \mathrm{inoculum}(\%), \mathrm{X}_{4}:$ temperature $\left({ }^{\circ} \mathrm{C}\right), \mathrm{X}_{4}$ \\
$\mathrm{NaCl}(\%)$ & & & & & \\
& & & & & \\
\hline
\end{tabular}

The ANOVA summary is shown in Table 4. The model $F$-value of 5.526 implied that the model was highly significant and there was only a 0.0011 chance that a model $F$-value could occurred due to noise. The fitness of the model was examined by determination coefficient $\left(\mathrm{R}^{2}=0.84\right)$, which implied that the sample variation of more than $84 \%$ was attributed to the variables and only less than $16 \%$ of the total variance could not be explained by the model.

In the analysis of regression (Table 4), the term of $\mathrm{X}_{3}$ (temperature), $\mathrm{X}_{4}(\mathrm{NaCl}), \mathrm{X}_{1}{ }^{2}$ (glucose), $\mathrm{X}_{3}^{2}, \mathrm{X}_{4}^{2}$ term $(P<0.05)$ were statistically significant on antimicrobial activity. Since the model showed insignificant lack of fit, the response was sufficiently explained by the regression equation. On the basis of $p$-values which are more than 0.05 , the generated regression relationship between inhibition index $(\mathrm{Y})$ and four variables (Table 4 and 5) were represented in Eq. (2).

$\mathrm{Y}=1.80-0.218 \mathrm{X}_{3}-0.223 \mathrm{X}_{4}-0.344 \mathrm{X}_{1}{ }^{2}-0.388 \mathrm{X}_{3}{ }^{2}-0.173 \mathrm{X}_{4}{ }^{2}$

Where $\mathrm{Y}$ is the predicted inhibition index yield, $\mathrm{X}_{1}$ is glucose, $\mathrm{X}_{3}$ is temperature and $\mathrm{X}_{4}$ is $\mathrm{NaCl}$. The values in this equation were derived from coefficient of intercept and significant variables (Table 5).

Table 4. ANOVA for Response Surface Quadratic ( $\mathrm{X}_{1}$,glucose; $\mathrm{X}_{2}$, inoculum; $\mathrm{X}_{3}$, Temperature; $\mathrm{X}_{4}$, $\mathrm{NaCl}$ )

\begin{tabular}{|c|c|c|c|c|c|c|}
\hline Sources & $\begin{array}{c}\text { Sum of } \\
\text { Squares }\end{array}$ & df & $\begin{array}{l}\text { Mean } \\
\text { Square }\end{array}$ & $\begin{array}{c}F- \\
\text { Value }\end{array}$ & $P>\mathrm{F}$ & Note \\
\hline Model & 9.834 & 14 & 0.702 & 5.526 & 0.0011 & * \\
\hline $\mathrm{X}_{1}$ & 0.465 & 1 & 0.465 & 3.659 & 0.0751 & \\
\hline $\mathrm{X}_{2}$ & 0.040 & 1 & 0.040 & 0.312 & 0.5849 & \\
\hline $\mathbf{X}_{3}$ & 1.137 & 1 & 1.137 & 8.942 & 0.0092 & \\
\hline $\mathbf{X}_{4}$ & 1.196 & 1 & 1.196 & 9.407 & 0.0078 & \\
\hline $\mathrm{X}_{1} \mathrm{X}_{2}$ & 0.000 & 1 & 0.000 & 0.003 & 0.9577 & \\
\hline $\mathrm{X}_{1} \mathrm{X}_{3}$ & 0.142 & 1 & 0.142 & 1.117 & 0.3074 & \\
\hline $\mathrm{X}_{1} \mathrm{X}_{4}$ & 0.011 & 1 & 0.011 & 0.089 & 0.7698 & \\
\hline $\mathrm{X}_{2} \mathrm{X}_{3}$ & 0.017 & 1 & 0.017 & 0.136 & 0.7179 & \\
\hline $\mathrm{X}_{2} \mathrm{X}_{4}$ & 0.075 & 1 & 0.075 & 0.587 & 0.4553 & \\
\hline $\mathrm{X}_{3} \mathrm{X}_{4}$ & 0.101 & 1 & 0.101 & 0.797 & 0.3861 & \\
\hline $\mathrm{X}_{1}{ }^{2}$ & 3.239 & 1 & 3.239 & 25.478 & 0.0001 & \\
\hline $\mathrm{X}_{2}{ }^{2}$ & 0.303 & 1 & 0.303 & 2.384 & 0.1434 & \\
\hline $\mathbf{X}_{3}^{2}$ & 4.137 & 1 & 4.137 & 32.547 & $<0.0001$ & \\
\hline $\mathbf{X}_{4}^{2}$ & 0.820 & 1 & 0.820 & 6.448 & 0.0227 & \\
\hline Residual & 1.907 & 15 & 0.127 & & & \\
\hline $\begin{array}{l}\text { Lack of } \\
\text { Fit }\end{array}$ & 1.663 & 10 & 0.166 & 3.412 & 0.0939 & ns \\
\hline $\begin{array}{l}\text { Pure } \\
\text { Error }\end{array}$ & 0.244 & 5 & 0.049 & & & \\
\hline $\begin{array}{l}\text { Cor } \\
\text { Total }\end{array}$ & 11.741 & 29 & & & & \\
\hline
\end{tabular}

The relationship between $X_{3}$ (temperature), $\mathrm{X}_{4}(\mathrm{NaCl})$ and the inhibition index yield is illustrated as a three dimensional representation of the response surfaces and two-dimensional contour plots generated by the model in Figure 1. From the response surface plots (a), it is easy and convenient to understand the interaction between two factors and also to locate their optimum levels. Figure 1 (a) and (b) reveal that the inhibition index yield increased with an increase in the amounts of the $\mathrm{NaCl}\left(\mathrm{X}_{4}\right)$ up to an optimum (maximum inhibition index yield) beyond which there was a decrease. $\mathrm{NaCl}\left(\mathrm{X}_{4}\right)$ had a similar trend to temperature $\left(\mathrm{X}_{3}\right)$. Relationship between $\mathrm{X}_{1}$ (glucose), $X_{3}$ (temperature) and relationship between $\mathrm{X}_{1}$ (glucose), $\mathrm{X}_{4}(\mathrm{NaCl})$ and the 
inhibition index yield are illustrated as a three dimensional representation of the response surfaces (a) and two-dimensional contour plots (b) generated by the model (Figure 2 and 3). The interaction term $\mathrm{X}_{1}, \mathrm{X}_{3}, \mathrm{X}_{4}$ with a positive regression coefficient in Eq. (2) provided evidence that the inhibition index yield was favored by an increase in the factor interactions up to a value beyond which there was a decline. The optimized concentrations of glucose, inoculum, temperature, and $\mathrm{NaCl}$ were $1.63 \%, 3.03 \%, 33.74^{\circ} \mathrm{C}$, and $3.4 \%$, respectively, with the maximum predicted of inhibition index of 1.916, which increased 3.56-fold compared to that of obtain in medium before optimization processes (inhibition index of 0.42). This result is confirmed when the optimum concentration of nutrition was used as the inhibition index increased by 3.12 -fold.

Table 5. Regression coefficients and significance of response surface quadratic $\quad\left(\mathrm{X}_{1}\right.$, glucose; $\mathrm{X}_{2}$, inoculum; $\mathrm{X}_{3}$, Temperature; $\mathrm{X}_{4}$, $\mathrm{NaCl})$

\begin{tabular}{lccccc}
\hline Factor & $\begin{array}{c}\text { Coefficient } \\
\text { Estimate }\end{array}$ & $\begin{array}{c}\text { df } \\
\text { Intercept }\end{array}$ & $\begin{array}{c}\text { Standard } \\
\text { Error }\end{array}$ & $\begin{array}{c}\text { 95\%CI } \\
\text { Low }\end{array}$ & $\begin{array}{c}95 \% \text { CI } \\
\text { High }\end{array}$ \\
\hline $\mathrm{X}_{1}$ & 0.139 & 1 & 0.146 & 1.492 & 2.113 \\
$\mathrm{X}_{2}$ & 0.041 & 1 & 0.073 & -0.016 & 0.294 \\
$\mathbf{X}_{\mathbf{3}}$ & $\mathbf{- 0 . 2 1 8}$ & 1 & 0.073 & -0.114 & 0.196 \\
$\mathbf{X}_{4}$ & $\mathbf{- 0 . 2 2 3}$ & 1 & 0.073 & -0.373 & -0.063 \\
$\mathrm{X}_{1} \mathrm{X}_{2}$ & -0.005 & 1 & 0.089 & -0.195 & -0.068 \\
$\mathrm{X}_{1} \mathrm{X}_{3}$ & -0.094 & 1 & 0.089 & -0.284 & 0.096 \\
$\mathrm{X}_{1} \mathrm{X}_{4}$ & -0.027 & 1 & 0.089 & -0.217 & 0.163 \\
$\mathrm{X}_{2} \mathrm{X}_{3}$ & -0.033 & 1 & 0.089 & -0.223 & 0.157 \\
$\mathrm{X}_{2} \mathrm{X}_{4}$ & 0.068 & 1 & 0.089 & -0.122 & 0.258 \\
$\mathrm{X}_{3} \mathrm{X}_{4}$ & -0.080 & 1 & 0.089 & -0.270 & 0.110 \\
$\mathbf{X}_{\mathbf{1}}{ }^{2}$ & $\mathbf{- 0 . 3 4 4}$ & 1 & 0.068 & -0.489 & -0.199 \\
$\mathrm{X}_{2}{ }^{2}$ & -0.105 & 1 & 0.068 & -0.250 & 0.040 \\
$\mathrm{X}_{3}{ }^{2}$ & -0.388 & 1 & 0.068 & -0.533 & -0.243 \\
\hline
\end{tabular}
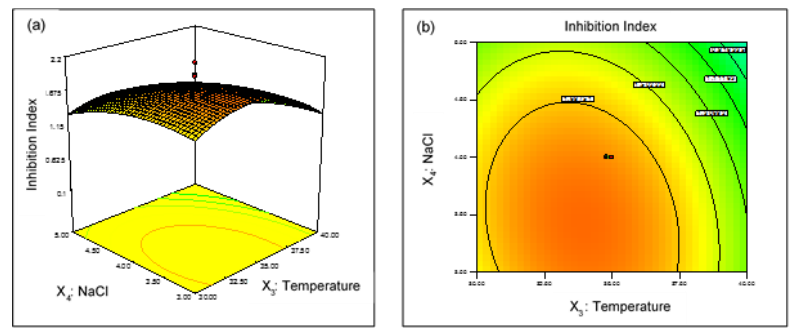

Figure 1. Response surface (a) and contour plots (b) for the effects temperature $\left(\mathrm{X}_{3}\right)$ and $\mathrm{NaCl}\left(\mathrm{X}_{4}\right)$ on inhibition index.
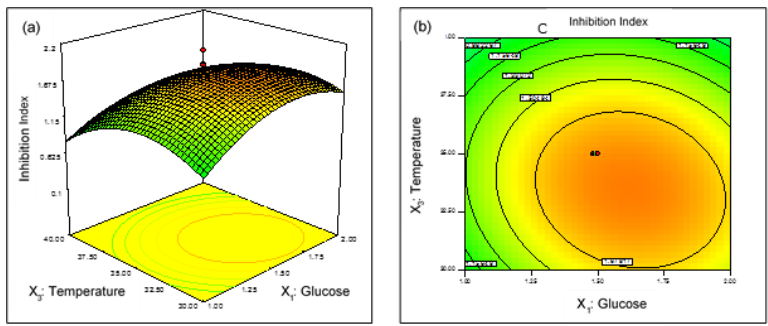

Figure 2. Response surface (a) and contour plots (b) for the effects glucose $\left(X_{1}\right)$ and temperature $\left(\mathrm{X}_{3}\right)$ on inhibition index.
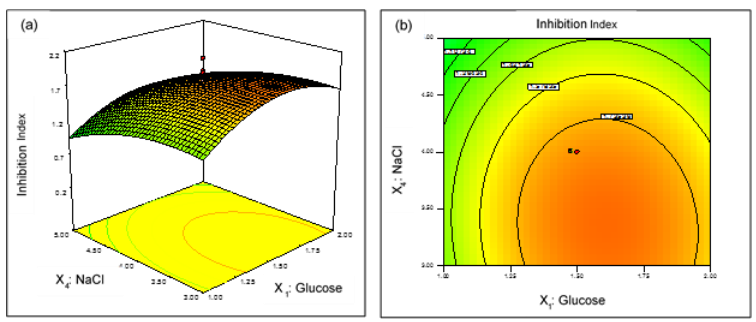

Figure 3. Response surface (a) and contour plots (b) for the effects glucose $\left(\mathrm{X}_{1}\right)$ and $\mathrm{NaCl}$ $\left(\mathrm{X}_{4}\right)$ on inhibition index.

\section{Discussion}

Intensive isolation and identification of LAB from fermented foods in Indonesia during the last 10 years resulted in the accumulation of LAB isolates and need to explore for its potential. This study is a dedication on further evaluation of LAB isolates for its ability to inhibit spoilage/food born pathogenic microorganisms present in food such as B. subtilis, E. coli, M. luteus, S. aureus, C. albicans, A. niger, and A. flavus. Those spoilage/food born pathogenic microbes were chosen as a model targets to screen LAB for its ability to have antimicrobial properties. B. subtilis could cause ropiness - a sticky, stringy consistency due to its ability in producing long-chain polysaccharides in spoiled bread dough (Pepe et al., 2003). E. coli is shown to cause diarrhea, cholecystitis, bacteremia, cholangitis, urinary tract infection (UTI), and other clinical infections such as neonatal meningitis and pneumonia (Vincent et al., 2010). Cases of bacteremia, endocarditis, ventriculitis, peritonitis, pneumonia, endophthalmitis, keratolysis and septic arthritis have been reported as a disease caused by the Micrococcus Species (Von Eiff et al., 1996). S. aureus can cause staphylococcal food poisoning via the 
production of enterotoxin. $S$. aureus is also a transient pathogenic microorganism of the scalded skin syndrome, bacteremia, toxic shock syndrome, and infections on medical implants (Foster, 2005). C. albicans can cause superficial infections such as oropharyngeal candidiasis (thrush) and vulvovaginal candidiasis (vaginal candidiasis). Oral candidiasis is common in elderly denture wearers (Darwazeh et al., 1990).

The nature of Aspergillus sp. (including A. niger and $A$. flavus) presence in nature and large amounts of aspergillus conidia (spores) being released into the air currents and available for inhalation, making the human pulmonary exposure to these organisms inevitable. Aspergillus species have emerged as important causes of morbidity and mortality in immunocompromised patients. Invasive aspergillosis currently constitutes the most common cause of infectious pneumonic mortality in patients undergoing HSCT (hematopoietic stem cell transplantation) and is an important cause of opportunistic respiratory and disseminated infection in other immunocompromised patients (Walsh et al., 2008; Person et al., 2010).

Wide ranges mode of action have been described for bacteriocins or antimicrobial, such as enzyme activity modulation, spores inhibition outgrowth and formation of pores in cell membrane. Most bacteriocins or antimicrobe interact with anionic lipids that are abundantly present in the membranes, and consequently initiate the formation of pores in the membranes of susceptible cells (Šušković et al., 2010).

In this study, $42.6 \%$ of $129 \mathrm{LAB}$ isolates show significant inhibition to test organisms with varying degrees. However, for the purpose of the study, only one isolate was selected, e.g. Lactobacillus plantarum LIPI132-LAB011 due to its broad spectrum nature relative to the other $\mathrm{LAB}$ species tested here.

Many studies show that LAB have antimicrobial activity. Spoilage or contamination of food caused by microbial spoilage can eventually be prevented by the addition of antimicrobial-producing LAB. Noordiana et al. (2013) have isolated and screened LAB strains (P1S1 and P3S3) from threadfin salmon and grass shrimp samples and found that they exhibited inhibitory effects against Salmonella typhimurium, Listeria monocytogenes, E. coli and B. cereus. They also stated that the antagonistic activity may have been due to the presence of organic acid, hydrogen peroxide and bacteriocin, which act as antibacterial substances. Desniar et al. (2013) reported that LAB from bekasam (Indonesian fermented fish) inhibited growth of L. monocytogenes, S. typhimurium, E. coli, $B$. cereus and $S$. aureus. The highest inhibition zone and inhibition index was on $S$. aureus. However, culture supernatant of the LAB isolates did not produce inhibition zone at neutral $\mathrm{pH}$. Their result indicated that inhibition activity of $\mathrm{LAB}$ isolated from Indonesian bekasam was from organic acids, and those organic acids are probably the main preservative factor in the bekasam.

Hwanhelm et al. (2011) studied that Streptococcus salivarius LD219, Enterococcus faecalis LPS04, E. faecalis LPS17 and E. faecalis LPS18, which were isolated from plasom (Thai fermented fish), had a good antimicrobial activity against foodborne pathogens (Salmonella sp., S. aureus and E. coli) as well as a good acidifying activity. Cizeikiene et al. (2013) stated that L. sakei KTU05-6, Pediococcus acidilactici KTU05-7, $P$. pentosaceus KTU05-8, KTU05-9 and KTU05-10 strains produced organic acids and bacteriocins-like inhibitory substances (BLIS) against pathogenic microorganisms (Bacillus, Pseudomonas, Listeria, Escherichia, Fusarium culmorum, Penicillium chrysogenum, A. fumigatus, A.versicolor, $P$. expansum, $A$. niger, Debaryomyces hansenii and $C$. parapsilosis genera in various degrees) in the food industry.

Our study shows that L. plantarum LIPI132-LAB011 has a broad spectrum that could inhibit four testing microorganisms and shows activity against Gram-positive bacteria i.e B. subtilis and $S$. aureus and fungi i.e C. albicans and $A$. niger. The strain was isolated from terasi (fermented shrimp) obtained from Sukawati Traditional Market in Bali, Indonesia using MRS medium $\mathrm{pH}$ 6.0. L. plantarum is a type of facultative anaerobic bacteria that can control the growth of microbial pathogens by producing organic acid, hydrogen peroxide, diacetyl and bacteriocin (Dalié et al., 2010). The ability of $L$. plantarum strain to display antimicrobial activity against pathogen has been published in several reports, for example L. plantarum MiLAB 14 produces hydroxylated fatty acids with strong antifungal effects in MRS medium, with total inhibitory 
effects of hydroxy fatty acids in the range of 10 to $>100 \mu \mathrm{g} . \mathrm{mL}^{-1}$ against several moulds and yeasts (Magnusson, 2003). Antifungal produced by L. plantarum DR 1-6-2 on MRS Agar medium against Aspergillus fumigatus and A. flavus by plate assay method (aerobic condition) had a percentage of inhibition of $41 \%$ and $32 \%$, respectively (Rohmatussolihat, 2013). This strain also produced antimicrobial that work against Penicillium by deep tube technique (anaerobic condition) (Rohmatussolihat, 2013). Lactobacillus plantarum ST16PA produced bacteriocin, which actively inhibited the growth of Enterobacter, Enterococcus, Lactobacillus, Pseudomonas, Streptococcus, Staphylococcus, and Listeria (Todorov et al., 2011). Lactobacillus plantarum LB-B1 from a traditionally fermented dairy product koumiss produced a bacteriocin active against Listeria, Lactobacillus, Streptococcus, Enterococcus, Pediococcus and Escherichia (Xie et al., 2011). Lactobacillus plantarum 21B was isolated from sourdough had antifungal activity. Growth of A. niger FTDC3227 in bread started with Lactobacillus plantarum 21B and Sacharomyces cerevisiae 141 could be delayed after 7 days of storage, while in bread started with Lactobacillus brevis and $S$. cerevisiae only after 2 days of storage (Lavermicocca et al., 2000).

In producing these antimicrobial compounds, it is interesting to evaluate the effect of nutrient composition of medium used. Evaluation of the nutritional and environmental requirements for microorganism to produce optimum antimicrobial should be an important stage in developing and determining the overall economic feasibility of its bioprocess. Environmental factors such as temperature, $\mathrm{pH}$ and media composition influence the level of production of antimicrobial substances. Nutrients in the production of antimicrobial substances and the different types of supplements added to the growth media at different concentrations could affect the quantity and ability to inhibit pathogenic bacteria (Widyaningsih et al., 2017). Optimization of cultural medium is a very important aspect in the field of food microbiology and fermentation ( $\mathrm{Mu}$ et al., 2009). The RSM has been a popular and effective method to solve multivariate problems and optimize several responses in many types of experiment (Wang \& Liu, 2008).

In this study, optimum glucose concentration at $1.63 \%$ increase the antimicrobial activity of $L$. plantarum LIPI132-LAB011 against $C$. Albicans. Todorov (2008) reported that L. plantarum AMA-K produced bacteriocin/antimicrobial AMA-K that inhibits the growth of Enterococcus sp., E. coli, Klebsiella pneumoniae and Listeria sp. The production of bacteriocin AMA-K of 100 $\%$ is stimulated when cells are grown in medium supplemented with $3 \%$ glucose. Glucose is main source of carbon, nutrients that are needed for growth of microorganisms. Bogaert and Naidu (2000) and Nelson \& Cox, (2008) stated that antimicrobial activity of LAB is mainly caused by organic acids produced through glucose catabolism (Embden Meyerhoff Parnas pathway). Vatanyoopaisarn et al. (2011) studied that the use of media without glucose inhibited the production of organic acids as antimicrobial substances.

This study unveiled that concentration of inoculum added in the culture media were statistically has no significant effect to the antimicrobial activity against $C$. albicans. This result is similar to Himelbloom et al. (2001) that different concentration of inoculum had no significant effect on the production of bacteriocin by L. acidophilus LF221 and Candida piscicola A9b. On the other hand, Taheri et al. (2012) studied that inoculum level significantly affected bacteriocin production by $L$. plantarum ST1. Maximum bacteriocin activity and stability $(640 \mathrm{AU} / \mathrm{ml})$ were obtained at the lowest inoculum level $(0.01 \%)$. The difference in results may be due to the type of bacterial strains, composition of medium production used, and also incubation conditions used in growing the inoculum.

In this study, optimum temperature for antimicrobial production against $C$. albicans from $L$. plantarum LIPI13-2-LAB011 was at $33.74^{\circ} \mathrm{C}$. Results were not different from those carried out by Kumar et al. (2012) that effective temperature for bacteriocin production by $L$. casei LA-1 ranged from 33.5 to $34.5{ }^{\circ} \mathrm{C}$. Martinez et al. (2013) reported that the optimal temperature range of $L$. plantarum ST71KS isolated from homemade goat feta cheese in producing antimicrobial against Listeria monocytogenes strains 603 and 607 was between $30-37{ }^{\circ} \mathrm{C}$. While, Malheiros et al. (2015) reported that higher amounts of 
bacteriocin as antimicrobial from L. case $i$ were produced when the incubation temperature was either $25{ }^{\circ} \mathrm{C}$ or $30^{\circ} \mathrm{C}$. The difference in results may be due to the type of bacterial strains and composition of medium production used.

Optimum concentration of $\mathrm{NaCl}$ for antimicrobial production against $C$. albicans from L. plantarum LIPI13-2-LAB011 is 3.4\%. According to Noordiana et al. (2013) the medium supplemented with $\mathrm{NaCl}(1 \%)$ significantly enhanced the antibacterial activity as shown by the P1S1 and P3S3 strains against E. coli, Staphylococcus typhimurium and L. monocytogenes. The results were the same as those expressed by Settanni et al. (2008), that the presence of $\mathrm{NaCl}$ (1- 2\%) improves LAB growth and increases bacteriocin activity.

In conclusion, out of 129 LAB isolates, 55 isolates $(42.6 \%)$ show significant inhibition against test organisms with varying degrees and 74 isolates $(57.4 \%)$ did not show inhibition. Only one isolate (L. plantarum LIPI13-2-LAB011) shows wide spectrum activity against four test organisms. Therefore, L. plantarum LIPI13-2-LAB011 was selected for optimization of antimicrobial production using CCD-RSM.

The optimized medium composition was $1.63 \%$ glucose, $3.03 \%$ inoculum, $33.74{ }^{\circ} \mathrm{C}$ temperature, $3.4 \% \mathrm{NaCl}$, with the maximum product of inhibition index (1.916) after $48 \mathrm{~h}$ fermentation, which corresponded to the results of RSM optimization.

\section{Acknowledgements}

This project was funded by SATREPS Project "Development of Internationally Standardized Microbial Resources Center As A Core of Biological Resources Center to Promote Life Science Research and Biotechnology (JST-JICA), Program 20112015. The authors acknowledge Ayu Syafitri for laboratory work.

\section{References}

Al-Allaf, M. A. H., Al-Rawi, A. M. M., \& AlMola, A. T. (2009). Antimicrobial activity of lactic acid bacteria isolated from minced beef meat against some pathogenic bacteria. Iraqi Journal of Veterinary Sciences, 23(3), 115-117.
Badis, A., Guetarni, D., Boudjema, B. M., Henni, D. E., \& Kihal, M. (2004). Identification and technological properties of lactic acid bacteria isolated from raw goat milk of four Algerian races. Food Microbiology, 21(5), 579-588.

Balouiri, M., Sadiki, M., \& Ibnsouda S.K. 2016. Methods for in vitro evaluating antimicrobial activity:Areview. Journal of Pharmaceutical Analysis, 6, 71-79.

Bezerra, M. A., Santelli, R. E., Oliveira, E. P., Villar, L. S., \& Escaleira, L. A. (2008). Response surface methodology (RSM) as a tool for optimization in analytical chemistry. Talanta, 76(5), 965-977.

Bogaert, J., \& Naidu, A. (2000). Natural Food Antimicrobial System. Florida (US): CRC Pr.

Bromberg, R., Moreno, I., Zaganini, C. L., Delboni, R. R., \& Oliveira, J. D. (2004). Isolation of bacteriocin-producing lactic acid bacteria from meat and meat products and its spectrum of inhibitory activity. Brazilian Journal of Microbiology, 35(1-2), 137-144.

Chauhan, K., Trivedi, U., \& Patel, K. C. (2007). Statistical screening of medium components by Plackett-Burman design for lactic acid production by Lactobacillus sp. KCP01 using date juice. Bioresource Technology, 98(1), 98103.

Cizeikiene, D., Juodeikiene, G., Paskevicius, A., \& Bartkiene, E. (2013). Antimicrobial activity of lactic acid bacteria against pathogenic and spoilage microorganism isolated from food and their control in wheat bread. Food Control, 31(2), 539-545.

Dalié, D. K. D., Deschamps, A. M., \& RichardForget, F. (2010). Lactic acid bacteria-Potential for control of mould growth and mycotoxins: A review. Food Control, 21(4), 370-380.

Darwazeh, A. M. G., Lamey, P. J., Samaranayake, L. P., MacFarlane, T. W., Fisher, B. M., Macrury, S. M., \& MacCuish, A. C. (1990). The relationship between colonisation, secretor status and in-vitro adhesion of Candida albicans to buccal epithelial cells from diabetics. Journal of Medical Microbiology, 33(1), 43-49.

Desniar, M. Rusmana, I., Suwanto, A. \& Mubarik, N. R. (2013). Characterization of lactic acid bacteria isolated from an Indonesian fermented fish (bekasam) and their antimicrobial activity against pathogenic bacteria. Emirates Journal of Food and Agriculture, 489-494.

Foster, T. J. (2005). Immune evasion by staphylococci. Nature Reviews Microbiology, 3(12), 948 .

Gálvez, A., Abriouel, H., López, R. L., \& Omar, N. B. (2007). Bacteriocin-based strategies for food biopreservation. International Journal of Food Microbiology, 120(1-2), 51-70.

Gálvez, A., López, R. L., Abriouel, H., Valdivia, E., \& Omar, N. B. (2008). Application of 
bacteriocins in the control of foodborne pathogenic and spoilage bacteria. Critical Reviews in Biotechnology, 28(2), 125-152.

Ghrairi, T., Frere, J., Berjeaud, J. M., \& Manai, M. (2008). Purification and characterisation of bacteriocins produced by Enterococcus faecium from Tunisian rigouta cheese. Food Control, 19(2), 162-169.

Himelbloom, B., Nilsson, L., \& Gram, L. (2001). Factors affecting production of an antilisterial bacteriocin by Carnobacterium piscicola strain A9b in laboratory media and model fish systems. Journal of Applied Microbiology, 91(3), 506-513.

Hwanhlem, N., Buradaleng, S., Wattanachant, S., Benjakul, S., Tani, A., \& Maneerat, S. (2011). Isolation and screening of lactic acid bacteria from Thai traditional fermented fish (Plasom) and production of Plasom from selected strains. Food Control, 22(3-4), 401-407.

Kadariya, J., Smith, T. C., \& Thapaliya, D. (2014). Staphylococcus aureus and staphylococcal food-borne disease: an ongoing challenge in public health. BioMed Research International, Article ID 827965, 9 pages.

Khurana, S., Kapoor, M., Gupta, S., \& Kuhad, R. C. (2007). Statistical optimization of alkaline xylanase production from Streptomyces violaceoruber under submerged fermentation using response surface methodology. Indian Journal of Microbiology, 47(2), 144-152.

Kumar, M., Jain, A. K., Ghosh, M., \& Ganguli, A. (2012). Statistical optimization of physical parameters for enhanced bacteriocin production by L. casei. Biotechnology and Bioprocess Engineering, 17(3), 606-616.

Lavermicocca, P., Valerio, F., Evidente, A., Lazzaroni, S., Corsetti, A., \& Gobbetti, M. (2000). Purification and characterization of novel antifungal compounds from the sourdough Lactobacillus plantarum strain 21B. Applied and Environmental Microbiology, 66(9), 4084-4090.

Leal-Sánchez, M. V., Jiménez-Díaz, R., Maldonado-Barragán, A., Garrido-Fernández, A., \& Ruiz-Barba, J. L. (2002). Optimization of bacteriocin production by batch fermentation of Lactobacillus plantarum LPCO10. Applied and Environmental Microbiology, 68(9), 4465-4471.

Liong, M. T., \& Shah, N. P. (2005). Production of organic acids from fermentation of mannitol, fructooligosaccharide and inulin by a cholesterol removing Lactobacillus acidophilus strain. Journal of Applied Microbiology, 99(4), 783-793.

Magnusson, J. (2003). Antifungal activity of lactic acid bacteria (Doctoral dissertation, Uppsala: Department of Microbiology, Swedish University of Agricultural).
Malheiros, P. S., Sant'Anna, V., Todorov, S. D., \& Franco, B. D. (2015). Optimization of growth and bacteriocin production by Lactobacillus sakei subsp. sakei 2a. Brazilian Journal of Microbiology, 46(3), 825-834.

Martinez, R. C. R., Wachsman, M., Torres, N. I., LeBlanc, J. G., Todorov, S. D., \& de Melo Franco, B. D. G. (2013). Biochemical, antimicrobial and molecular characterization of a noncytotoxic bacteriocin produced by Lactobacillus plantarum ST71KS. Food Microbiology, 34(2), 376-381.

Martins, N., Ferreira, I. C., Barros, L., Silva, S., \& Henriques, M. (2014). Candidiasis: predisposing factors, prevention, diagnosis and alternative treatment. Mycopathologia, 177(56), 223-240.

Miyadoh, S., \& Otoguro M. 2004. Workshop on Isolation Method and Clasification of Actinomycetes. Bogor (ID): LIPI Bioteknologi.

Mu, W., Chen, C., Li, X., Zhang, T., \& Jiang, B. (2009). Optimization of culture medium for the production of phenyllactic acid by Lactobacillus sp. SK007. Bioresource Technology, 100(3), 1366-1370.

Nelson, D.L., \& Cox, M.M. (2008). Lehninger: Principles of Biochemistry, fifth edition. Madison Avenue (NY): WH Freeman Comp.

Noordiana, N., Fatimah, A. B., \& Mun, A. S. (2013). Antibacterial agents produced by lactic acid bacteria isolated from Threadfin Salmon and Grass Shrimp. International Food Research Journal, 20(1), 117-124.

Pepe, O., Blaiotta, G., Moschetti, G., Greco, T., \& Villani, F. (2003). Rope-producing strains of Bacillus spp. from wheat bread and strategy for their control by lactic acid bacteria. Applied and Environmental Microbiology, 69(4), 2321-2329.

Person, A. K., Chudgar, S. M., Norton, B. L., Tong, B. C., \& Stout, J. E. (2010). Aspergillus niger: an unusual cause of invasive pulmonary aspergillosis. Journal of Medical Microbiology, 59(7), 834-838.

Rajendran, A., \& Thangavelu, V. (2007). Sequential optimization of culture medium composition for extracellular lipase production by Bacillus sphaericus using statistical methods. Journal of Chemical Technology and Biotechnology, 82(5), 460-470.

Rohmatussolihat. (2013). Seleksi dan optimasi bakteri asam laktat penghasil senyawa antikapang (Magister Tesis, Bogor: Institut Pertanian Bogor).

Saranraj, P. (2012). Microbial spoilage of bakery products and its control by preservatives. International Journal of Pharmaceutical \& Biological Archive, 3(1), 38-48.

Saranya, S., \& Hemashenpagam, N. (2011). Antagonistic activity and antibiotic sensitivity of lactic acid bacteria from fermented dairy 
products. Advances in Applied Science Research, 2(4), 528-534.

Settanni, L., Valmorri, S., Suzzi, G., \& Corsetti, A. (2008). The role of environmental factors and medium composition on bacteriocin-like inhibitory substances (BLIS) production by Enterococcus mundtii strains. Food Microbiology, 25(5), 722-728.

Šušković, J., Kos, N., Beganović, Pavunc, A.L., Habjanić, K., \& Matosić, S. (2010). Antimicrobial activity - The most important property of probiotic and starter lactic acid bacteria. Food Technol Biotechnol 48 (3) 296307.

Taheri, P., Samadi, N., Ehsani, M. R., Khoshayand, M. R., \& Jamalifar, H. (2012). An evaluation and partial characterization of a bacteriocin produced by Lactococcus lactis subsp lactis ST1 isolated from goat milk. Brazilian Journal of Microbiology, 43(4), 1452-1462.

Tan, P., Peh, K., Gan, C., \& Liong, M. T. (2014). Bioactive dairy ingredients for food and nonfood applications. Acta Alimentaria, 43(1), 113123.

Todorov, S. D. (2008). Bacteriocin production by Lactobacillus plantarum AMA-K isolated from Amasi, a Zimbabwean fermented milk product and study of the adsorption of bacteriocin AMA-K to Listeria sp. Brazilian Journal of Microbiology, 39(1), 178-187.

Todorov, S. D., Prévost, H., Lebois, M., Dousset, X., LeBlanc, J. G., \& Franco, B. D. (2011). Bacteriocinogenic Lactobacillus plantarum ST16Pa isolated from papaya (Carica papaya)-From isolation to application: Characterization of a bacteriocin. Food Research International, 44(5), 1351-1363.

Valerio, F., De Bellis, P., Lonigro, S. L., Visconti, A., \& Lavermicocca, P. (2008). Use of Lactobacillus plantarum fermentation products in bread-making to prevent Bacillus subtilis ropy spoilage. International Journal of Food Microbiology, 122(3), 328-332.

Vatanyoopaisarn, S., Prapatsornwattana, K., Kuhakongkeat, T., \& Phalakornkule, C. (2011). Potential use of lactic acid bacteria with bacteriocin-like activity against Staphylococcus aureus as dual starter cultures in Thai fermented sausage" Sai Krok Prew.". International Food Research Journal, 18(2), 697-704.

Vincent, C., Boerlin, P., Daignault, D., Dozois, C. M., Dutil, L., Galanakis, C., Reid-Smith, R. J., Tellier, P. P., Tellis, P. A., Ziebell, K., \& Manges, A. R. (2010). Food reservoir for Escherichia coli causing urinary tract infections. Emerging Infectious Diseases, 16(1), 88.

Von Eiff, C., Kuhn, N., Herrmann, M., Weber, S., \& Peters, G. (1996). Micrococcus luteus as a cause of recurrent bacteremia. The Pediatric Infectious Disease Journal, 15(8), 711-713.
Walsh, T. J., Anaissie, E. J., Denning, D. W., Herbrecht, R., Kontoyiannis, D. P., Marr, K. A., Morrison, V. A., Segal, B. H., Steinbach, W. J., Stevens, D. A., \& van Burik, J. A. (2008). Treatment of aspergillosis: clinical practice guidelines of the Infectious Diseases Society of America. Clinical Infectious Diseases, 46(3), 327-360.

Wang, Z. W., \& Liu, X. L. (2008). Medium optimization for antifungal active substances production from a newly isolated Paenibacillus sp. using response surface methodology. Bioresource Technology, 99(17), 8245-8251.

Wessels, S., Axelsson, L., Hansen, E. B., De Vuyst, L., Laulund, S., Lähteenmäki, L., Lindgren, S., Mollet, B., Salminen, S., \& von Wright, A. (2004). The lactic acid bacteria, the food chain, and their regulation. Trends in Food Science \& Technology, 15(10), 498-505.

Widyaningsih, S., Trianto, A., Radjasa, O.K., Wittriansyah K. (2018). Antibacterial activity symbiotic fungi of marine sponge Axinella sp., Aspergillus Sydowii on four growth medium. IOP Conf. Series: Earth and Environ Science 116, 1-9.

Xie, Y., An, H., Hao, Y., Qin, Q., Huang, Y., Luo, Y., \& Zhang, L. (2011). Characterization of an anti-Listeria bacteriocin produced by Lactobacillus plantarum LB-B1 isolated from koumiss, a traditionally fermented dairy product from China. Food Control, 22(7), 1027-1031.

Yang, E., Fan, L., Jiang, Y., Doucette, C., \& Fillmore, S. (2012). Antimicrobial activity of bacteriocin-producing lactic acid bacteria isolated from cheeses and yogurts. Amb Express, 2(1), 48.

Yu, L., Lei, T., Ren, X., Pei, X., \& Feng, Y. (2008). Response surface optimization of 1-(+)-lactic acid production using corn steep liquor as an alternative nitrogen source by Lactobacillus rhamnosus CGMCC 1466. Biochemical Engineering Journal, 39(3), 496-502.

Yuan, L. L., Li, Y. Q., Wang, Y., Zhang, X. H., \& $\mathrm{Xu}$, Y. Q. (2008). Optimization of critical medium components using response surface methodology for phenazine-1-carboxylic acid production by Pseudomonas sp. M-18Q. Journal of Bioscience and Bioengineering, 105(3), 232-237. 